\title{
PERAN AUDIT FEE, JASA NON AUDIT, LAMA HUBUNGAN AUDIT DAN UKURAN KAP TERHADAP INDEPENDENSI AUDITOR
}

\author{
Gde Herry Sugiarto Asana ${ }^{1}$ \\ Komang Krishna Yogantara ${ }^{2}$ \\ Fakultas Bisnis, Universitas Triatma Mulya, Bali, Indonesia ${ }^{1,2}$ \\ email: gdeherrysa@gmail.com
}

\begin{abstract}
Independence is a free mental attitude and is not controlled by other parties as well as the honesty of Auditors in consideration, formulating and expressing opinions. The purpose of this research is to obtain empirical evidence of the influence of Audit Fee, Non-audit services, old audit relations and size of public accountant office on the Independence of Auditors. The population of this research is the Auditor of the public Accountant office registered in the IAPI Directory in 2019. Data collection is performed using questionnaires. The number of samples in this study was 66 respondents using the purposive Sampling method with the criteria of auditors working at least 1 year. The data analysis technique used was multiple linear regression with the help of SPSS version 25.0 program. The results showed that (1) the Audit Fee significantly affects the independence of the Auditor, (2) Non-Audit services have no significant effect on the independence of the Auditor, (3) The length of the audit relationship has significant effect on the independence of the Auditor, (4) The size of the public Accountant Office has no significant effect on the independence of Auditors. (5) Audit Fee, Non-Audit services, length of audit relationship and size of public accountant office simultaneously have significant effect on the independence of Auditors. Thus, to enhance or maintain independence, auditors should avoid variables that can affect independence.
\end{abstract}

Keywords: $\quad$ audit fee, non-audit services, length of audit relationship, size of public accountant office and independence.

\section{PENDAHULUAN}

Profesi akuntan publik merupakan salah satu profesi yang mendapat kepercayaan dari masyarakat umum. Sehingga dari profesi ini masyarakat mengharapkan penilaian yang bebas dan tidak memihak terhadap informasi yang disajikan oleh pihak manajemen perusahaan dalam laporan keuangan. Guna menunjang profesionalismenya sebagai akuntan publik maka auditor harus berpedoman pada standar audit yang telah ditetapkan oleh Institut Akuntan Publik Indonesia (IAPI) dalam melaksanakan tugasnya.
Standar auditing merupakan panduan umum bagi auditor dalam memenuhi tanggung jawab profesinya untuk melakukan audit atas laporan keuangan historis. Standar ini mencakup pertimbangan atas kualitas profesional seperti kompetensi dan independensi, persyaratan pelaporan serta bukti audit. Standar audit meliputi standar umum, standar pekerja lapangan dan standar pelaporan. Dimana standar umum merupakan cerminan kualitas pribadi yang harus dimiliki seorang auditor dalam melaksanakan prosedur audit. 
Sedangkan standar pekerja lapangan dan standar pelaporan mengatur seorang auditor dalam pengumpulan data dan kegiatan lain yang dilaksanakan selama melakukan audit serta mewajibkan auditor menyusun laporan keuangan yang diaudit secara keseluruhan. Selain standar audit, seorang akuntan publik juga harus mematuhi kode etik profesi atau etika profesional yang mengatur perilaku akuntan publik dalam menjalankan praktik profesinya baik dengan anggota maupun dengan masyarakat umum. Secara umum ada 6 prinsip etika profesi yaitu tanggungjawab, kepentingan publik, integritas, kecermatan dan keseksamaan, lingkungan dan sifat jasa, objektivitas dan independensi.

Independensi adalah sikap mental yang tidak terpengaruh, tidak dikendalikan dan tidak bergantung kepada orang lain serta adanya kejujuran dalam diri auditor dalam mempertimbangkan sebuah fakta dan adanya pertimbangan yang objektif, tidak memihak dalam merumuskan dan menyatakan pendapat. Mulyadi (2002) menyatakan bahwa terdapat beberapa keadaan yang sering kali mengganggu sikap mental independensi auditor adalah 1) Sebagai seorang yang melaksanakan audit secara independen, auditor dibayar oleh kliennya atas jasanya tersebut, 2) Sebagai penjual jasa seringkali auditor mempunyai kecenderungan untuk memuaskan klien, 3) Mempertahankan sikap mental independensinya seringkali dapat menyebabkan lepasnya klien.

Sikap independen auditor juga dapat tercermin dalam penentuan audit fee atas pekerjaan audit yang dilaksanakannya. Audit fee merupakan imbalan yang diterima oleh akuntan publik dari entitas kliennya sehubungan dengan pemberian jasa audit. Institut Akuntan Publik Indonesia (2016) besarnya audit fee bervariasi tergantung dari faktor-faktor dalam penugasan audit. Besar kecilnya audit fee dapat ditentukan oleh kompleksitas audit yang dilakukan, tingkat keahlian auditor, resiko audit yang dihadapi auditor, usaha untuk mendapatkan serta mempertahankan klien dan pertimbangan profesional lainnya. Penelitian yang dilakukan oleh Manuaba dan Utama (2015) menyatakan bahwa audit fee berpengaruh signifikan terhadap independensi dan penelitian yang dilakukan oleh Sianipar dan Darsono (2017) menyatakan besarnya biaya jasa audit berpengaruh positif signifikan terhadap independensi auditor . Sedangkan penelitian yang dilakukan oleh Setyono (2016) menyatakan bahwa audit fee tidak berpengaruh signifikan terhadap independensi auditor.

Salah satu contoh kasus pelanggaran sikap independensi adalah kasus manipulasi laporan keuangan perusahaan multipembiayaan PT. Sunprima Nusantara Pembiayaan (SNP) tahun 2017. PT. SNP merupakan anak usaha Columbia Group, perusahaan pembiayaan perabot rumah tangga dan retail. Manipulasi laporan keuangan SNP ini melibatkan dua akuntan publik yaitu Akuntan Publik Marlinna, Akuntan Publik Merliyana Syamsul dan satu kantor akuntan publik yaitu Kantor Akuntan Publik Satrio, Bing Eny dan Rekan. KAP Satrio, Bing Eny dan Rekan merupakan partner local dari KAP internasional Deloitte yang termasuk firma empat besar global. Atas kesalahan audit laporan keuangan 
tersebut, Otoritas jasa Keuangan (OJK) menjatuhkan sanksi kepada para akuntan publik tersebut karena dianggap melakukan kesalahan dalam audit laporan keuangan. Sanksi tersebut berupa pencabutan dan pembatalan izin operasi atau audit sektor jasa keuangan seperti perbankan, multipembiayaan, asuransi, dan industri jasa keuangan lainnya. Hasil penilaian OJK bahwa AP Marlinna dan AP Merliyana Syamsul telah melakukan pelanggaran berat sehingga melanggar POJK Nomor 13/POJK.03/2017 Tentang Penggunaan Jasa Akuntan Publik dan Kantor Akuntan Publik.

Pada dasarnya akuntan publik menyediakan berbagai jasa bagi masyarakat, jasa yang diberikan suatu kantor akuntan publik dapat diklasifikasikan menjadi dua, yaitu jasa audit dan jasa non audit. Auditor memberikan jasa non audit berupa jasa akuntansi dan pembukuan, jasa perpajakan, dan jasa konsultasi manajemen. Hasil dari penelitianpenelitian sebelumnya mengenai variabel jasa non audit menunjukkan hasil yang tidak konsisten. Terlihat pada penelitian yang dilakukan oleh Manuaba dan Utama (2015) menyatakan bahwa jasa non audit berpengaruh signifikan terhadap independensi auditor. Sedangkan penelitian yang dilakukan oleh Setyono (2016) menyatakan jasa non audit tidak berpengaruh terhadap independensi auditor.

Lama hubungan audit dengan klien adalah lamanya waktu auditor melakukan pemeriksaan terhadap suatu unit-unit usaha perusahaan atau instansi. hubungan yang lama antara auditor dengan kliennya akan menimbulkan hubungan seperti kekeluargaan atau lebih dari rekan kerja, sehingga akan membuat auditor cenderung mengikuti keinginan kliennya meskipun auditor harus melanggar standar-standar audit untuk memberikan opini yang diinginkan kliennya atau membuat opini yang tidak sesuai dengan kondisi kliennya. Penelitian yang dilakukan Hanif (2014) menyatakan lama hubungan berpengaruh signifikan terhadap independensi auditor. Sedangkan penelitian yang dilakukan oleh Sianipar dan Darsono (2017) menyatakan bahwa lama hubungan audit tidak memiliki pengaruh terhadap independensi auditor.

AICPA menggolongkan besar kecilnya ukuran kantor akuntan publik dikatakan besar jika kantor akuntan publik tersebut telah melaksanakan audit pada perusahaan go-public, dan dikatakan kecil jika akuntan publik tersebut belum melakukan audit pada perusahaan go-public. Penelitian yang dilakukan oleh Setyono (2016) menunjukkan bahwa ukuran KAP berpengaruh signifikan terhadap independensi auditor dan penelitian yang dilakukan oleh Rakai dan Kartika (2015) menyatakan bahwa ukuran KAP berpengaruh positif signifikan terhadap independensi auditor. Sementara penelitian yang dilakukan oleh Putri, dkk (2014) yang menyatakan bahwa ukuran KAP tidak berpengaruh terhadap independensi auditor.

Berdasarkan pemaparan latar belakang di atas maka rumusan masalah dalam penelitian ini adalah

1) Apakah peran audit fee berpengaruh terhadap independensi auditor KAP di Bali?

2) Apakah peran jasa non audit berpengaruh terhadap independensi auditor KAP di Bali? 
3) Apakah peran lama hubungan audit berpengaruh terhadap independensi auditor KAP di Bali?

4) Apakah peran ukuran KAP berpengaruh terhadap independensi auditor KAP di Bali?

\section{TINJAUAN PUSTAKA}

\section{Theory of attitude and behaviour}

Teori sikap dan perilaku etis (Theory of attitude and behaviour) yang dikembangkan oleh Triandis (1980) dalam Soegiastuti (2005:7-8), dipandang sebagai teori yang dapat menjelaskan independensi. Teori tersebut menyatakan, bahwa perilaku menentukan untuk apa orang-orang ingin lakukan (sikap), apa yang mereka pikirkan akan mereka lakukan (aturan-aturan sosial), apa yang mereka bisa lakukan (kebiasaan), dan dengan konsekuensi perbuatan yang mereka pikirkan. Sikap adalah keadaan dalam diri manusia yang menggerakkan untuk bertindak, serta menyertai manusia dengan perasaan tertentu dalam menanggapi objek yang terbentuk atas dasar pengalaman. Sikap merupakan kecendrungan dalam merespon sesuatu. Sikap bukanlah perilaku, namun sikap merupakan wahana dalam membimbing perilaku. Perilaku etis adalah perilaku yang sesuai norma-norma sosial yang diterima secara umum, yang berhubungan dengan tindakantindakan yang bermanfaat maupun tindakan yang berbahaya.

Teori ini menjelaskan tentang aspek perilaku manusia di dalam suatu organisasi, khususnya akuntan publik atau auditor dalam berperilaku independen ketika melaksanakan tugas audit. Suatu kinerja auditor dapat diukur dengan karakteristik personal auditor dalam melaksanakan pekerjaan. Jika seorang auditor memiliki sikap yang sesuai dengan etika yang berlaku, maka kinerja auditor yang dihasilkan akan semakin baik.

\section{Independensi}

Menurut Mulyadi (2002) independensi berarti adanya kejujuran dalam diri auditor dalam mempertimbangkan fakta dan adanya pertimbangan yang objektif dalam merumuskan dan menyatakan pendapat. Selain mempertahankan sikap mental independen, auditor juga diharapkan mampu menghindari keadaan yang mengakibatkan masyarakat meragukan independensinya. Dengan demikian, disamping auditor harus benar-benar independen, auditor juga harus menimbulkan persepsi dikalangan masyarakat bahwa ia benar-benar independen. Munawir (1995:35) menyatakan sikap mental independensi mencakup dua aspek yaitu pertama independensi dalam fakta (in fact) merupakan kemampuan auditor untuk bersikap bebas, jujur dan objektif dalam melakukan penugasan penugasan audit. Kedua independensi dalam penampilan (in appearance) merupakan independen yang dipandang dari pihak-pihak yang berkepentingan terhadap perusahaan yang diaudit yang mengetahui hubungan antara auditor dengan kliennya.

\section{Audit Fee}

Audit fee merupakan pendapatan yang diterma oleh kantor akuntan publik setelah melaksanakan jasa auditnya. Mulyadi (2002) menyatakan besarnya fee anggota kantor akuntan publik dapat bervariasi tergantung pada risiko penugasan, kompleksitas jasa yang diberikan, tingkat keahlian dan struktur biaya 
kantor akuntan publik yang bersangkutan.

Jasa Non Audit

Mulyadi (2002) menyatakan jasa non audit adalah jasa yang dihasilkan oleh akuntan publik yang didalamnya memberikan suatu pendapat, ringkasan temuan atau bentuk lain keyakinan. Jenis jasa non audit yang dihasilkan oleh kantor akuntan publik adalah jasa akuntansi, jasa perpajakan dan jasa konsultasi manajemen.

\section{Lama Hubungan Audit}

Menurut Peraturan Menteri Keuangan No. 17/0MK.01/2008 menyatakan pemberian jasa audit umum atas laporan keuangan dari suatu entitas dilakukan KAP paling lama untuk tahun buku berturut-turut dan oleh seorang akuntan publik paling lama 3 tahun buku berturutturut.

\section{Ukuran KAP}

Arens, et al (2003) menjelaskan bahwa ukuran KAP merupakan ukuran yang digunakan untuk menentukan besar kecilnya suatu kantor akuntan publik. Ukuran kanor akuntan publik dapat dikatakan besar jika KAP tersebut berafiliasi dengan big four, mempunyai cabang dan kliennya perusahaan-perusahaan besar serta mempunyai tenaga profesional diatas 25 orang. Sedangkan KAP dikatakan kecil jika KAP tersebut tidak berafiliasi dengan big four, tidak mempunyai cabang dan kliennya perusahaan-perusahaan kecil serta mempunyai tenaga profesional kurang dari 25 orang.

\section{Pengaruh Audit Fee terhadap Independensi Auditor}

Audit fee merupakan imbalan yang diterima oleh kantor akuntan publik dari klien tertentu sesuai dengan luas dan lingkup pemeriksaan serta tingkat kesulitan yang dihadapi auditor sebagaimana disepakati dalam kontrak audit (Darmayanthi dan Wirakusuma, 2017). Retty dan Kusuma (2001) berpendapat audit fee yang jumlahnya besar kemungkinan akan mengakibatkan berkurangnya independensi auditor yang disebabkan oleh auditor yang menerima audit fee besar merasa tergantung pada klien tersebut sehingga segan menentang pendapat kliennya dan auditor yang menerima audit fee besar dari klien takut kehilangan sebagian besar pendapatnya sehingga auditor cenderung tidak independen. Hal ini diperkuat oleh penelitian yang dilakukan oleh Manuaba dan Utama (2015) menyatakan bahwa audit fee berpengaruh signifikan terhadap independensi auditor, maka hipotesis dalam penelitian ini adalah:

$\mathrm{H}_{1}$ : Audit fee berpengaruh terhadap independensi auditor.

Pengaruh Jasa Non Audit terhadap Independensi Auditor

Menurut Mulyadi (2002:6) jasa non audit adalah jasa yang dihasilkan oleh akuntan publik yang di dalamnya memberikan suatu pendapat, ringkasan temuan, atau bentuk lain keyakinan. Kantor akuntan publik selain memberikan jasa audit juga memberikan jasa lain, misalnya jasa perpajakan, jasa konsultasi manajemen serta jasa akuntansi dan pembukuan. Pemberian jasa lain memungkinkan hilangnya independensi akuntan publik atau auditor karena akuntan publik atau auditor akan cenderung memihak kepada kepentingan kliennya. Selain itu pemberian jasa lain selain audit dapat membuat kantor akuntan merasa harga dirinya dipertaruhkan untuk keberhasilan kliennya dan mungkin juga mengharuskan kantor akuntan 
publik membuat keputusan tertentu untuk klien sehingga akuntan publik menjadi tidak independen. Penelitian yang dilakukan oleh Hanif (2014) menyatakan bahwa jasa selain audit berpengaruh signifikan terhadap independensi auditor. Berdasarkan uraian diatas, maka hipotesis dalam penelitian ini adalah:

$\mathrm{H}_{2}$ : Jasa non audit berpengaruh terhadap independensi auditor.

\section{Pengaruh Lama Hubungan Audit terhadap Independensi Auditor}

Lama hubungan audit yaitu lamanya jangka waktu pemberian jasa audit kepada klien tertentu oleh suatu kantor akuntan publik (Shockley,1981). Hubungan audit antara kantor akuntan publik dengan klien dibatasi hanya 6 tahun, sedangkan untuk partner paling lama 3 tahun. Penugasan lebih dari 6 tahun dianggap dapat mempengaruhi independensi auditor karena dapat menimbulkan hubungan yang tertutup, sehingga kantor akuntan publik lebih memperhatikan kepentingan klien dan kurang ketat dalam melaksanakan prosedur audit. Hasil penelitian tersebut didukung oleh Pratomo dan Lestari (2010) menyatakan bahwa lama hubungan audit berpengaruh signifikan terhadap independensi auditor, maka hipotesis dalam penelitian ini adalah:

$\mathrm{H}_{3}$ : $\begin{aligned} & \text { Lama hubungan audit } \\ & \text { berpengaruh } \\ & \text { independensi auditor. }\end{aligned}$
terhadap

\section{Pengaruh Ukuran KAP terhadap Independensi Auditor}

Penggolongan ukuran besar kecilnya kantor akuntan publik sesuai dengan AICPA dikatakan besar jika kantor akuntan publik tersebut telah melaksanakan audit pada perusahaan go-public, dikatakan kecil jika akuntan publik tersebut belum melakukan audit pada perusahaan go-public. Kantor akuntan publik yang besar lebih independen dibandingkan dengan kantor akuntan publik yang lebih kecil, alasannya bahwa kantor akuntan publik besar apabila kehilangan satu klien tidak begitu berpengaruh terhadap pendapatannya, sehingga independensi auditor terjaga, sedangkan kantor akuntan publik yang kecil apabila kehilangan satu kliennya adalah sangat berarti karena kliennya sedikit. Hal ini didukung oleh penelitian yang dilakukan oleh Setyono (2016) menyatakan bahwa ukuran KAP berpengaruh signifikan terhadap independensi auditor, maka hipotesis dalam penelitian ini adalah:

$\mathrm{H}_{4}$ : Ukuran KAP berpengaruh terhadap independensi auditor.

\section{METODE PENELITIAN}

Menurut Nazir (2014:70) semua proses yang dibutuhkan dalam perencanaan dan pelaksanaan penelitian disebut desain penelitian. Penelitian ini menggunakan metode deskriptif dengan menggunakan pendekatan kuantitatif. Penelitian deskriptif kuantitatif adalah data yang diperoleh dari sampel populasi penelitian dianalisis sesuai dengan metode statistik yang digunakan untuk menghasilkan sebuah kesimpulan. Populasi dalam penelitian ini adalah seluruh auditor Kantor Akuntan Publik di Bali yang terdaftar di Directory IAPI tahun 2019 sebanyak 107 auditor. Pemilihan sampel dalam penelitian menggunakan purposive sampling dengan kriteria auditor yang bekerja minimal 1 tahun pada Kantor Akuntan Publik. Auditor yang telah bekerja minimal 1 tahun telah memiliki pemahaman yang cukup berkaitan dengan profesi auditor serta 
mampu beradaptasi dengan budaya perusahaaan.

Metode pengumpulan data pada penelitian ini adalah metode survey dengan teknik kuesioner. Menurut Sugiyono (2014:142) kuesioner adalah teknik pengumpulan data yang efisien apabila peneliti tahu dengan siapa variabel akan diukur dan tahu apa yang bisa diharapkan dari responden. Dalam melakukan pengukuran atas pernyataan menggunakan skala likert 4 (empat) poin guna mengurangi bias hasil penelitian atas jawaban netral atau ragu-ragu dari responden. Teknik analisis data yang digunakan dalam penelitian ini adalah analisis regresi linier berganda dengan menggunakan bantuan program aplikasi SPSS (Statistical Package for Social Sciences) versi 25.0.

\section{HASIL DAN PEMBAHASAN}

Kuesioner yang disebarkan kepada responden yaitu sebanyak 96 kuesioner dari 13 KAP di Bali yang diperoleh dari seluruh populasi sebanyak 107 auditor dikurangi dengan auditor yang bekerja kurang dari 1 tahun sebanyak 11 auditor. Berdasarkan hasil pengamatan terdapat 3 KAP yang tidak ikut berpartisipasi diantaranya KAP Rama Wendra dan KAP Tjahjo, Machdjud Modopuro \& Rekan menolak mengisi kuesioner dikarenakan sebagian besar karyawannya mendapat tugas diluar serta tidak menyebar kuesioner pada KAP Drs. Ida Bagus Djagera karena KAPnya sudah tidak beroperasi lagi. Sehingga jumlah kuesioner yang ditolak sebanyak 13 kuesioner dan yang kembali sebanyak 83 kuesioner. Setelah dilakukan pemeriksaan, terdapat 17 kuesioner yang digugurkan karena tidak melengkapi data pada pernyataan dalam kuesioner, sehingga secara keseluruhan terdapat 66 kuesioner yang layak untuk dianalisis. Hasil Uji Instrumen Uji Validitas
Suatu instrumen dikatakan valid apabila nilai Pearson Correlation lebih besar dari 0,30. Hasil uji validitas dalam penelitian ini menunjukkan seluruh nilai koefisien korelasi dari instrumen ini lebih besar dari 0,30 , sehingga instrumen ini dapat dikatakan valid.

\section{Uji Reliabilitas}

Suatu instrument dikatakan reliabel apabila memiliki Cronbach Alpha lebih besar dari 0,60. Hasil uji reliabilitas dalam penelitian ini menunjukkan seluruh nilai koefisien Cronbach Alpha dari instrumen lebih besar dari 0,60, sehingga instrumen dari penelitian ini dapat dikatakan reliabel.

\section{Hasil Uji Asumsi Klasik} Uji Normalitas

Berdasarkan hasil uji
normalitas menunjukkan nilai
Asymp.Sig. (2-tailed) sebesar 0,200
atau $\geq \alpha=0,05$, sehingga
kesimpulannya adalah residual telah
berdistribusi normal, oleh karena itu
asumsi normalitas residual telah
terpenuhi.

Uji Multikolinearitas

Berdasarkan hasil uji multikolinearitas menunjukkan bahwa nilai VIF yang dihasilkan kurang dari 10 dan koefisien tolerance yang dihasilkan lebih besar dari 0,10 untuk setiap variabel bebas yang digunakan, sehingga dapat disimpulkan bahwa tidak terjadi multikolinearitas antar variabel bebas.

\section{Uji Heteroskedastisitas}

Berdasarkan hasil uji Glejser menunjukkan nilai signifikan yang dihasilkan pada semua variabel bebas 
lebih besar dari 0,05 sehingga tidak Hasil Uji Regresi Linear Berganda terjadi heteroskedastisitas.

\section{TABEL 1}

HASIL UJI REGRESI LINEAR BERGANDA

\begin{tabular}{|c|c|c|c|c|c|c|}
\hline & \multirow[b]{2}{*}{ Model } & \multicolumn{2}{|c|}{$\begin{array}{c}\text { Unstandardized } \\
\text { Coeffisients } \\
\text { Std. }\end{array}$} & \multicolumn{2}{|l|}{$\begin{array}{l}\text { Standardized } \\
\text { Coefficients }\end{array}$} & \multirow[b]{2}{*}{ Sig. } \\
\hline & & $\mathrm{B}$ & Error & Beta & $\mathrm{T}$ & \\
\hline \multirow[t]{5}{*}{1} & (Constant) & 13,169 & 1,173 & & 11,222 & 000 \\
\hline & Audit fee & ,237 & ,041 & 464 & 5,753 & ,000 \\
\hline & Jasa non audit &,- 002 & ,040 &,- 003 &,- 039 & 969 \\
\hline & Lama hubungan audit & ,311 & ,047 & ,532 & 6,588 & 000 \\
\hline & Ukuran KAP &,- 007 & ,045 &,- 011 &,- 144 & 886 \\
\hline
\end{tabular}

\section{Sumber: data diolah (2020)}

\section{a. Dependent Variable: Independensi Auditor}

\begin{abstract}
Berdasarkan hasil analisis regresi linear berganda yang ditunjukkan pada Tabel 1, maka dapat dibuat persamaan regresi sebagai berikut:

$\mathrm{Y}=13,169+0,237 \mathrm{X}_{1}-0,002 \mathrm{X}_{2}+$ $0,311 \mathrm{X}_{3}-0,007 \mathrm{X}_{4}+\mathrm{e} \ldots \ldots \ldots \ldots 1$
\end{abstract}

\section{Hasil Uji t}

Hasil pengujian hipotesis satu $\left(\mathrm{H}_{1}\right)$ menunjukkan bahwa audit fee berpengaruh signifikan terhadap independensi auditor KAP di Bali. Hal ini ditunjukkan oleh nilai koefisien beta unstandardized variabel audit fee sebesar 0,242 dan (sig.) t sebesar 0,000 . Hal ini sesuai dengan penelitian yang dilakukan oleh Mahsun (2016) menyatakan audit fee berpengaruh signifikan terhadap independensi auditor. Hasil penelitian ini juga didukung oleh penelitian Manuaba dan Utama (2015) yang menyatakan audit fee berpengaruh signifikan terhadap independensi auditor. Sikap dan perilaku auditor yang mudah dipengaruhi oleh fee maka akan membuat akuntan publik merasa tergantung dengan kliennya dan segan untuk menentang keinginan maupun kehendak dari kliennya.

Hasil pengujian hipotesis dua $\left(\mathrm{H}_{2}\right)$ menunjukkan bahwa jasa non audit tidak berpengaruh signifikan terhadap independensi auditor KAP di Bali. Hal ini ditunjukkan oleh nilai koefisien beta unstandardized dari variabel jasa non audit adalah sebesar $-0,002$ dan (sig.) t sebesar 0,969. Hasil penelitian ini didukung oleh penelitian Mahsun (2016) yang menyatakan jasa selain audit tidak berpengaruh signifikan terhadap independensi auditor. auditor memberikan layanan jasa non audit maka akan meningkatkan manfaat informasi yang diperlukan serta membantu auditor mengetahui keadaan dari kliennya sehingga relatif mempunyai kekuatan untuk menghadapi tekanan dari klien dan mempertahankan sikap independensinya

Hasil pengujian hipotesis tiga $\left(\mathrm{H}_{3}\right)$ menunjukkan bahwa lama hubungan audit berpengaruh signifikan terhadap independensi auditor KAP di Bali. Hal ini ditunjukkan oleh nilai koefisien beta unstandardized variabel lama hubungan audit sebesar 0,304 dan (sig.) $\mathrm{t}$ sebesar 0,000 . Penelitian ini sejalan dengan penelitian dari Manuaba dan Utama (2015) menyatakan lama hubungan audit 
berpengaruh signifikan terhadap independensi auditor. Fenomena saling membutuhkan dapat timbul apabila terjalin hubungan yang lama antara auditor dengan klien dan menyebabkan pola hubungan auditor dan klien tersebut menjadi partner kerja.

Hasil pengujian hipotesis empat $\left(\mathrm{H}_{4}\right)$ menunjukkan bahwa ukuran KAP tidak berpengaruh signifikan terhadap independensi auditor KAP di Bali. Hal ini ditunjukkan oleh nilai koefisien beta Unstandarsized dari variabel Ukuran KAP adalah sebesar -0,007 dan (sig.) t sebesar 0,886. Hasil penelitian ini tidak sejalan dengan penelitian Sari dan Suryono (2016) yang menyatakan ukuran KAP berpengaruh negatif dan signifikan terhadap independensi auditor. Berkaitan dengan sikap dan perilaku etis, independensi auditor akan semakin ditekankan pada ukuran KAP yang besar agar para auditor dalam melaksanakan tugasnya tetap berpegang teguh pada sikap profesionalnya, hal ini dikarenakan reputasi yang baik yang akan diterima KAP dari kliennya.

Hasil uji F

TABEL 2

HASIL UJI F

\begin{tabular}{llrrrrl}
\hline & Model & $\begin{array}{c}\text { Sum of } \\
\text { Squares }\end{array}$ & df & $\begin{array}{c}\text { Mean } \\
\text { Square }\end{array}$ & \multicolumn{1}{c}{ F } & Sig. \\
\hline \multirow{2}{*}{1} & Regression & 126,063 & 4 & 31,516 & 25,965 & 0,000 \\
& Residual & 76,467 & 63 & 1,214 & & \\
& Total & 202,529 & 67 & & & \\
\hline
\end{tabular}

Sumber: data diolah (2020)

Tingkat probabilitas (sig.) F yang diperoleh dari hasil pengujian pada Tabel 2 di atas adalah $0,000 \leq$ 0,05, yang berarti $\mathrm{H}_{1}$ diterima dan $\mathrm{H}_{0}$ ditolak, sehingga dapat disimpulkan bahwa variabel audit fee $\left(\mathrm{X}_{1}\right)$, jasa non audit $\left(\mathrm{X}_{2}\right)$, lama hubungan audit $\left(\mathrm{X}_{3}\right)$ dan ukuran KAP $\left(\mathrm{X}_{4}\right)$ secara simultan berpengaruh signifikan terhadap variabel independensi auditor (Y).

Hasil Uji Koefisien Determinasi

TABEL 3

HASIL UJI KOEFISIEN DETERMINASI

\begin{tabular}{|c|c|c|c|c|}
\hline Model & $\mathrm{R}$ & $R$ Square & $\begin{array}{c}\text { Adjusted } R \\
\text { Square }\end{array}$ & $\begin{array}{l}\text { Std. Error of } \\
\text { the Estimate }\end{array}$ \\
\hline 1 & ,798 &, 636 &, 612 & 1,073 \\
\hline
\end{tabular}

$\overline{\text { Predictors (Constant), Ukuran KAP, Jasa non audit, Lama hubungan audit, Audit }}$ fee

Sumber: data diolah (2020)

Hasil uji koefisien determinasi ditunjukkan dengan nilai Adjusted $R$ pada Tabel 3 adalah sebesar 0,612 .
Nilai determinasinya menjadi $0,612 \mathrm{x}$ $100 \%=61,2 \%$. Hal tersebut menunjukkan bahwa variabilitas 
variabel audit $f e e$, jasa non audit, lama hubungan audit dan ukuran KAP sebesar $61,2 \%$ sedangkan sisanya sebesar $38,8 \%$ dijelaskan oleh variabel-variabel lain yang tidak diteliti dalam penelitian ini.

\section{SIMPULAN DAN SARAN Simpulan}

Simpulan yang diperoleh dari penelitian ini adalah:

1. Audit fee berpengaruh signifikan terhadap independensi auditor KAP di Bali. Dengan demikian besarnya audit fee dapat mempengaruhi independensi auditor karena fee yang besar dapat membuat akuntan publik menjadi segan untuk menentang keinginan atau kehendak dari kliennya.

2. Jasa non audit tidak berpengaruh signifikan terhadap independensi auditor KAP di Bali. Dengan demikian pemberian jasa non audit kepada klien akan membantu auditor dalam memahami dan mengetahui keadaan dari kliennya sehingga relatif mempunyai kekuatan untuk menghadapi tekanan dari klien dan mempertahankan sikap independensinya.

3. Lama hubungan audit berpengaruh signifikan terhadap independensi auditor KAP di Bali., semakin erat jalinan hubungan antara auditor dengan klien seringkali mengakibatkan sulitnya untuk menegakkan independensi. Selain itu hubungan yang lama antara auditor dengan kliennya akan menimbulkan hubungan seperti kekeluargaan atau lebih dari rekan kerja, sehingga akan membuat auditor cenderung mengikuti keinginan kliennya.
4. Ukuran KAP tidak berpengaruh signifikan terhadap independensi auditor KAP di Bali. Dengan demikian ukuran KAP yang besar lebih independen dibandingkan KAP yang kecil, karena jika KAP besar kehilangan satu klien tidak berpengaruh terhadap pendapatannya dan KAP besar umum dianggap penyedia kualitas audit tinggi, memiliki reputasi tinggi di lingkungan bisnis serta mampu menahan tekanan dari kliennya.

5. Berdasarkan hasil uji simultan Audit fee, jasa non audit, lama hubungan audit dan ukuran KAP secara simultan berpengaruh signifikan terhadap independensi auditor KAP di Bali. Dengan demikian, apabila auditor ingin mempertahankan atau meningkatkan sikap independensi maka harus menghindari variabel yang dapat mempengaruhi independensi auditor.

\section{Saran}

Berdasarkan hasil penelitian dan beberapa kendala yang dihadapi dalam penelitian ini, maka masih diperlukan pengembangan dan perbaikan guna memperoleh hasil penelitian yang lebih baik pada penelitian-penelitian selanjutnya. Beberapa saran yang dapat disampaikan adalah:

1. Bagi auditor KAP di Bali diharapkan agar seorang auditor dapat berperilaku sesuai dengan kode etik profesi dan menghindari faktor-faktor yang dapat mempengaruhi independensinya.

2. Fokus penelitian ini adalah auditor KAP di Bali, sehingga hasil penelitian ini tidak dapat digeneralisasikan untuk seluruh KAP di Indonesia. Penelitian ini 
dapat dijadikan pertimbangan oleh penelitian selanjutnya dengan menambahkan variabel bebas lain seperti persaingan antar KAP, profil KAP, ikatan kepentingan keuangan dan hubungan usaha dengan klien.

\section{DAFTAR PUSTAKA}

Arens, Alvin. K, dan Loebbecke, J. K. 2003. Auditing. Jakarta: Salemba Empat.

Darmayanthi, Anak Agung Eka dan Wirakusuma, Made Gede. 2017. Pengaruh Ikatan Kepentingan Keuangan, Fee Audit, Sifat Machiavellian dan Pemahaman Etika pada Independensi Penampilan Auditor. E-Jurnal Akuntansi: 30-59.

Hanif, Rheny Afriana. 2014. Audit fee, Jasa Selain Audit, Profil Kantor Akuntan Publik, Lama Hubungan Audit dengan Klien terhadap Independensi Akuntan Publik di Pekanbaru dan Medan. Jurnal Ekonomi, 22(3), 154-167.

Institut Akuntan Publik Indonesia (IAPI). 2016. Peraturan Pengurus Nomor 2 Tahun 2016 Tentang Penentuan Imbalan Jasa Audit Laporan Keuangan. Jakarta.

Institut Akuntan Publik Indonesia (IAPI), Indonesian Institute of Certified Public Accountants (IICPA), 2019, Directory Kantor Akuntan Publik dan Akuntan Publik 2019, Penerbit Institut Akuntan Publik Indonesia (IAPI), Indonesian $\begin{array}{rr}\text { Institute of } & \text { Certified Public } \\ \text { Accountants } & \text { (IICPA) } \\ \text { bekerjasama } & \text { dengan }\end{array}$

Republik Indonesia, Sekretaris Jendral Pusat Pembinaan Profesi Keuangan, http:iapilib.com/directory-

2019/\#p=203. diunduh pada tanggal 16 September 2019 , pada pukul $10.00 \mathrm{WIB}$.

Mahsun, Mohammad. 2016. Pengaruh Audit Fee Dan Jasa Selain Audit Terhadap Independensi Auditor Pada Kantor Akuntan Publik di Yogyakarta. Doctoral Dissertation. STIE Widya Wiwaha.

Manuaba, Ida Bagus Ananta Aditama dan Utama, I Made Karya. 2015. Pengaruh Audit Fee, Non-Audit Services dan Audit Tenure pada Independensi Auditor. E-Jurnal Akuntansi: 1164-1189.

Mulyadi. 2002. Auditing (Edisi 5). Jakarta. Salemba Empat.

Munawir, H.S. 1995. Auditing Modern. Edisi Pertama. Yogyakarta: BPFE.

Nazir, Moh. 2014. Metode Penelitian. Bogor Ghalia Indonesia.

Peraturan Menteri Keuangan No. 17/PMK.01/2008 Tentang Jasa Akuntan Publik.

Pratomo, Rudi dan Lestari. 2010. Pengaruh Audit Fee, Jasa Selain Audit, Profil KAP, Hubungan Audit Lama KAP dengan Klien terhadap 
Journal of Applied Management and Accounting Science ( J A M A S )

(Gde Herry Sugiarto Asana, Komang Krishna Yogantara 41 - 52)

Vol 2, No 1, Desember 2020

Independensi Auditor KAP di Surabaya. Balance Economic, Business, Management and Accounting Journal 7(01).

Putri, Kirana, Hardi Hardi, Sem Paulus Silalahi. 2014. Analisis FaktorFaktor Yang Mempengaruhi Independensi Akuntan Publik Dalam Pelaksanaan Audit (Study Survey pada Kantor Akuntan Publik di Pekanbaru dan Batam). Doctoral Dissertation. Riau University.

Rakai, Brilian Akbar dan Kartika, Andi. 2015. Faktor-Faktor Yang Mempengaruhi Independensi Auditor di Jawa Tengah (Studi Empiris pada Kantor Akuntan Publik di Jawa Tengah). Journal. Dinamika Akuntansi Keuangan dan Perbankan 4(2).

Retty dan Kusuma. 2001. Analisis Faktor-Faktor Yang Mempengaruhi Independensi Penampilan Akuntan Publik. Jurnal Akuntansi dan Auditing Indonesia Vol.5 No.1 Hal.1-3.

Sari, Septanika Amala Kartika \& Suryono, Bambang. 2016. Pengaruh Audit Fee, Ukuran KAP dan Lamanya Hubungan Audit terhadap Independensi Auditor. Jurnal Ilmu dan Riset Manajemen (JIRM), 5(10).

Setyono, Unggul. 2016. Analisis Faktor-Faktor Yang Berpengaruh Terhadap Independensi Auditor (Studi Empiris Pada Kantor Akuntan Publik Semarang. Journal of Accounting 2(2).
Shockley, Randoph A. 1981. Perceptions of Auditor's Independence: An Empiricial Analysis. The Accounting Review.

Sianipar, Hendry Prawira dan Darsono. 2017. Faktor-Faktor Yang Mempengaruhi Independensi Auditor (Studi Empiris pada KAP di Jawa Tengah). Doctoral Dissertation. Fakultas Ekonomika dan Bisnis.

Soegiastuti, Janti. 2005. Persepsi Masyarakat tentang Independensi Auditor dalam Penampilan. Tesis. Program Studi Magister Akuntansi Program Pascasarjana Universitas Diponegoro Semarang.

Sugiyono. 2014. Metode Penelitian Manajemen. Bandung. Alfabeta.

Triandis, HC. 1980. Values, Attitudes, and Interpersonal Behavior. In University of Nebraska (Lincoln campus). Dept. of Psychology. (Ed.). Nebraska Symposium on Motivation (pp.196-259). Uviversity of Nebraska Press. 